\title{
Prevalence and Risk of Gingival Enlargement in Patients Treated With Nifedipine
}

\author{
Jaume Miranda, ${ }^{*}$ Lluís Brunet, * Pere Roset, ${ }^{\dagger}$ Leonardo Berini, ${ }^{\dagger}$ Magí Farré,${ }^{\dagger}$ and Carlos Mendieta*
}

Background: Gingival enlargement is a known side effect of nifedipine use. This study was conducted to determine the prevalence and risk factors for gingival enlargement in nifedipinetreated patients.

Methods: A cross-sectional study was conducted in a primary care center. Data from 65 patients taking nifedipine were compared with 147 controls who had never received the drug. All patients were examined for the presence of gingival enlargement using 2 different indices: vertical gingival overgrowth index (GO) in 6 points around each tooth, and horizontal MB index in the interdental area. Gingival index, plaque index, and probing depth were also evaluated.

Results: The prevalence of gingival enlargement was significantly higher in nifedipine-treated cases than in controls (GO index, $33.8 \%$ versus $4.1 \%$; MB index, $50.8 \%$ versus $7.5 \%$, respectively). Higher gingival and plaque indices were observed in patients taking nifedipine. Among the possible risk factors, only the gingival index showed a significant association with gingival enlargement. The risk (odds ratio [OR]) of gingival enlargement associated with nifedipine therapy was $10.6(3.8-29.1)$ for the GO index and 14.4 (6-34.6) for the MB index. Gingival index-adjusted ORs were 9.6 (3.3-28.1) and 9.7 (3.9-23.3), respectively. In the subset of high nifedipine exposure patients, the odds ratio for gingival enlargement increased to 17.4 (5.356.3) for the GO index and 23.6 (7.7-72.3) for the MB index. The concordance between GO and MB indices showed a kappa value of 0.689 in controls and 0.642 in patients treated with nifedipine.

Conclusions: Patients taking nifedipine are at high risk for gingival enlargement, and gingivitis acts as a predisposing factor. J Periodontol 2001;72:605-611.

\section{KEY WORDS}

Cross-sectional studies; gingival hyperplasia/epidemiology; nifedipine/adverse effects; risk factors.

\footnotetext{
* Periodontics Unit, Facultat d'Odontologia, Universitat de Barcelona, Barcelona, Spain.

$\dagger$ Unit of Pharmacology, Institut Municipal d'Investigació Mèdica, Facultat de Medicina,

Universitat Autònoma de Barcelona.

‡ Oral Surgery Unit, Facultat d'Odontologia, Universitat de Barcelona.
}

$\longrightarrow$ ingival enlargement or overgrowth has been associated with multiple factors including inflammation, adverse drug effects, and neoplastic conditions. Chronic inflammation due to dental plaque frequently causes gingival overgrowth. ${ }^{1-4}$ Drugs associated with gingival enlargement include antiepileptics such as phenytoin; $;^{5-7}$ cyclosporin $A ; 8-16$ and calcium channel blockers, such as dihydropyridine, ${ }^{17-22}$ verapamil, ${ }^{23-27}$ and diltiazem. ${ }^{27-32}$ The clinical and pathologic features in drug-induced gingival overgrowth are independent of the drug administered, which suggests a common pathway of induction. ${ }^{33}$ The pathogenic mechanisms involve different factors, such as dental plaque, presence of genetically predetermined gingival fibroblasts (named responders), and effect of the drug itself, with all compounds affecting the transmembrane flow of calcium. ${ }^{12,34,35}$ This, in turn, changes the metabolism of connective tissue fibroblasts, causing an increase in the components of the extracellular matrix, i.e., collagen fibers and/or ground substance. ${ }^{22,36-43}$

Nifedipine is a calcium channel-blocking agent of the dihydropyridine group widely used as a vasodilating agent for the treatment of hypertension and ischemic heart disease. ${ }^{44,45}$ Gingival enlargement in patients treated with this drug was originally reported in 1984 by Lederman et al. ${ }^{19}$ and Ramon et al. ${ }^{21}$ More recently, gingival enlargement also has been described in patients treated with other dihydropyridines, such as nitrendi- 
pine, nicardipine, felodipine, and amlodipine. ${ }^{46-52}$ Because the majority of studies are based on series of cases with a small number of patients, the true prevalence of nifedipine-induced gingival enlargement is unknown. ${ }^{17,27,53-56}$ On the other hand, predictors of gingival enlargement in patients treated with nifedipine have not been previously assessed. Therefore, the aim of the present study was to determine the prevalence, severity, and risk factors of gingival enlargement in a population of nifedipine-treated patients and to compare the results with those in a control group.

\section{MATERIALS AND METHODS}

\section{Study Population}

A cross-sectional study was carried out at the CAPRambla primary care center serving a population of 170,000 inhabitants in Terrassa, Barcelona, Spain. All patients over 18 years of age treated with nifedipine who were consecutively visited by their general practitioner or cardiologist were eligible. Patients were included if they were currently taking nifedipine in regular doses during at least the last 6 months. The presence of at least 16 permanent teeth, with a minimum of 10 anterior teeth, was required. Patients who had undergone periodontal treatment within the 6 months prior to the initiation of the study; with concomitant systemic disorders known to affect the gums (such as diabetes, endocrine disorders, leukemia, thrombocytopenic purpura, or immunodeficiency states); or taking anticonvulsant drugs, calcium antagonists other than nifedipine, cyclosporin A, oral contraceptives, and sexual hormones were excluded from the study. ${ }^{18}$ The control group included patients not treated with nifedipine who fulfilled the same inclusion and exclusion criteria. All patients agreed to participate in the study and gave their written informed consent.

Gingival enlargement was graded according to the index originally described by Angelopoulos and Goaz ${ }^{5}$ and later modified by Miller and Damm ${ }^{24}$ (GO index). The height of gingival tissue was measured from the cemento-enamel junction (CEJ) to the free gingival margin. The following grades were scored in 6 points around each tooth: grade 0 , normal gingiva; 1 , minimal enlargement $(\leq 2 \mathrm{~mm}$ in size, with gingiva covering the cervical third or less of the anatomic crown); 2 , moderate enlargement ( 2 to $4 \mathrm{~mm}$ in size and/or gingiva extending into the middle third of the anatomic crown); and 3, severe enlargement (nodular growth $>4 \mathrm{~mm}$ and/or gingiva covering more than two-thirds of the tooth crown). Gingival overgrowth was also measured in the buccal-lingual direction in all interdental papilla according to the index described by Seymour et al. ${ }^{57}$ and modified by Miranda et al. (MB index). ${ }^{58}$ The increase in size of the papilla was measured from the enamel surface, at the interdental contact point, to the outer papillary surface. Two scores were obtained, one for the buccal papilla and another for the lingual/palatal papilla, according to the following criteria: grade 0 , papillary thickness of less than $1 \mathrm{~mm} ; 1$, papillary thickness between 1 and $2 \mathrm{~mm}$; and 2, papillary thickness $>2 \mathrm{~mm}$.

A standard periodontal probe (Michigan 8/11) was used to assess the extent of enlargement. For both indices, an average mean was calculated for the whole mouth, anterior and posterior areas, and buccal and lingual/palatal surfaces. Gingival enlargement was considered to be present when grades other than zero were recorded in one or in both $\mathrm{GO}$ and $\mathrm{MB}$ indices.

Other measures included the Löe and Silness gingival index (GI), ${ }^{59}$ plaque index (PI), ${ }^{60}$ and periodontal probing depth (PD). ${ }^{61}$ These indices were measured in 6 points around each tooth. All measurements were done by the same examiner (JM).

\section{Statistical Analysis}

The sample size was estimated considering a prevalence of gingival enlargement of $20 \%$ in nifedipinetreated patients and $4 \%$ in controls. ${ }^{27,62}$ Sixty-two patients treated with nifedipine would provide an $80 \%$ power to detect a difference in gingival enlargement of $5 \%$ at a $P<0.05$ significance level. ${ }^{63}$ The chi-square $\left(\chi^{2}\right)$ test and the Fisher's exact test were used to compare data in nifedipine-treated patients and controls. The influence of different factors such as age, gender, GI, PI, and other patient characteristics was assessed, exploring their associations with gingival enlargement in either treated or non-treated patients. A multiple logistic regression analysis was used to assess the risk associated with treatment (odds ratio [OR]) taking into account the above factors. The kappa index was calculated to assess the degree of concordance between the $\mathrm{GO}$ and $\mathrm{MB}$ indices.

\section{RESULTS}

The total study population was 212: 65 nifedipinetreated subjects and 147 controls. Demographic characteristics are shown in Table 1 . The distribution by gender was similar in both groups. Nifedipine-treated patients were older than controls (61.5 years versus 50.5 years, $P<0.0001$ ). Bruxism was slightly more prevalent in nifedipine-treated patients than in controls (30.8\% versus $18.4 \%, P=0.0450)$. Tobacco smoking was less prevalent in the nifedipine-treated group (6.2\% versus $11.6 \%, P=0.0352)$.

The prevalence of all clinical measurements was significantly higher in nifedipine-treated patients than in controls (Table 2): GO index $=1,33.8 \%$ versus $4.1 \%, P<0.0001 ;$ MB index $=1,50.8 \%$ versus $7.5 \%, P$ $<0.0001$; $\mathrm{GI}>1.5,49.2 \%$ versus $32.7 \%, P=0.0217$; PI $>2.5,75.4 \%$ versus $56.5 \%, P=0.0088$; mean $\mathrm{PD}>3$ $\mathrm{mm}, 40 \%$ versus $8.8 \%, P<0.0001$. 
Table I.

\section{Patient Demographic Characteristics}

\begin{tabular}{lccccc}
\hline & $\begin{array}{c}\text { Nifedipine-Treated } \\
(\mathrm{n}=65)\end{array}$ & \multicolumn{2}{c}{$\begin{array}{c}\text { Controls } \\
(\mathrm{n}=147)\end{array}$} & P Value \\
\cline { 2 - 5 } Characteristic & $\mathrm{N}$ & $\%$ & $\mathrm{~N}$ & $\%$ & \\
\hline Male/female & $23 / 42$ & $65 / 35$ & $69 / 78$ & $53 / 47$ & NS \\
Mean age, years (SD) & 61.5 & & 50.5 & & $<0.0001$ \\
& $(8.5)$ & & $(15.7)$ & & \\
Age & & & & & $<0.0001 *$ \\
18-28 & 0 & 0.0 & 18 & 12.2 & \\
29-45 & 1 & 1.5 & 29 & 19.7 & \\
$\quad 63-62$ & 34 & 52.3 & 66 & 45.0 & \\
Smokers (>20 cigarettes/day) & 30 & 46.2 & 34 & 23.1 & \\
Bruxism & 4 & 6.2 & 17 & 11.6 & 0.0352 \\
Oral breathing pattern & 20 & 30.8 & 27 & 18.4 & 0.0450 \\
Dental prosthesis & 6 & 9.2 & 24 & 16.3 & NS \\
\hline
\end{tabular}

* Chi-square analysis collapsing categories: age $=\leq 45,>45$.

Table 2.

\section{Periodontal Evaluation of Control and Nifedipine-Treated Patients}

\begin{tabular}{|c|c|c|c|c|c|}
\hline \multirow[b]{2}{*}{ Criteria } & \multicolumn{2}{|c|}{$\begin{array}{l}\text { Nifedipine-Treated } \\
\quad(n=65)\end{array}$} & \multicolumn{2}{|c|}{$\begin{array}{l}\text { Controls } \\
(n=147)\end{array}$} & \multirow[t]{2}{*}{$P$ Value } \\
\hline & $\mathrm{N}$ & $\%$ & N & $\%$ & \\
\hline \multicolumn{6}{|l|}{$\begin{array}{l}\text { Vertical gingival enlargement } \\
\text { (GO index) }\end{array}$} \\
\hline 0 & 43 & 66.2 & $|4|$ & 95.9 & \\
\hline । & 22 & 33.8 & 6 & 4.1 & \\
\hline 2 & 0 & 0.0 & 0 & 0.0 & \\
\hline 3 & 0 & 0.0 & 0 & 0.0 & \\
\hline \multirow{2}{*}{\multicolumn{6}{|c|}{$\begin{array}{l}\text { Horizontal nodullary-papilla } \\
\text { enlargement (MB index) }\end{array}$}} \\
\hline & & & & & $<0.000$ I* \\
\hline 0 & 32 & 49.2 & 136 & 92.5 & \\
\hline 1 & 33 & 50.8 & $\mid 1$ & 7.5 & \\
\hline 2 & 0 & 0.0 & 0 & 0.0 & \\
\hline Gingival index (Gl) & & & & & 0.0217 * \\
\hline$\leq 1.5$ & 33 & 50.8 & 99 & 67.3 & \\
\hline$>1.5$ & 32 & 49.2 & 48 & 32.7 & \\
\hline Plaque index (PI) & & & & & $0.0088 *$ \\
\hline$\leq 2.5$ & 16 & 24.6 & 64 & 43.5 & \\
\hline$>2.5$ & 49 & 75.4 & 83 & 56.5 & \\
\hline Probing depth & & & & & $<0.000 \mid$ * \\
\hline$\leq 3$ & 39 & 60.0 & 134 & 91.2 & \\
\hline$>3$ & 26 & 40.0 & 13 & 8.8 & \\
\hline
\end{tabular}

* Chi-square analysis collapsing categories: $\mathrm{GO}=0,>0 ; \mathrm{MB}=0,>0 ; \mathrm{GI}=\leq 1.5,>1.5 ; \mathrm{PI}=\leq 2.5,>2.5$; $\mathrm{PD}=\leq 3,>3$.
About $50 \%$ of patients in the nifedipine group had been taking the drug for more than 2 years, with $85 \%$ of the patients at doses between 30 to $60 \mathrm{mg} /$ day. According to the level of exposure (total accumulated dose) to nifedipine, patients were divided in 2 groups: high exposure $=10$ to $32 \mathrm{~g}$ and low exposure $=2$ to $9.9 \mathrm{~g}$ (Table 3 ). In the high exposure group, a higher prevalence of gingival enlargement (for both GO and $M B$ indices) was shown, but the differences were not statistically significant.

The bivariate analysis in both groups with respect to quantitative (GI, PI, PD) and qualitative variables (gender, age, smoking, bruxism, oral breathing pattern, and the presence of dental prosthesis) only showed a significant association between gingival enlargement ( $\mathrm{GO}$ and $\mathrm{MB}$ indices) and GI $(P<0.001)$

Results of multivariate analysis showed that the risk (odds ratio) for gingival enlargement associated with nifedipine treatment was 10.6 (3.8 to 29.1) for the GO index and 14.4 (6 to 34.6) for the MB index. When the odds ratios were adjusted for GI values, the risk of gingival enlargement was 9.6 (3.3 to 28.1) for the GO index and 9.7 (3.9 to 23.3) for the MB index. In the subset of high nifedipine exposure patients, the corresponding figures were 17.4 (5.3 to 56.3) for the GO index, 23.6 (7.7 to 72.3) for the MB index, and 9.0 (2.5 to 32.7) and 9.4 (3 to 28.9) when adjusted for GI (Table 4.)

The level of concordance between $\mathrm{GO}$ and $\mathrm{MB}$ indices in the control group and in nifedipine-treated patients showed a kappa value of 0.689 and 0.642 , respectively.

\section{DISCUSSION}

In a sample of the general population (control group), we found a prevalence of gingival enlargement of $4.1 \%$ (GO index) and 7.5\% (MB index). These findings are similar to those reported by Steele et al. ${ }^{27}$ By contrast, patients treated with nifedipine showed a prevalence of gingival enlargement of $34 \%$ and $51 \%$ according to the $\mathrm{GO}$ and $\mathrm{MB}$ indices, respectively. Data reported by others vary between $24 \%$ to 
Table 3.

\section{Periodontal Evaluations According to Length of Nifedipine Use}

\begin{tabular}{|c|c|c|c|c|c|}
\hline \multirow[b]{2}{*}{ Criteria } & \multicolumn{2}{|c|}{$\begin{array}{l}\text { Low Exposure: } \\
\text { Accumulated Dose } \\
\begin{array}{c}2 \text { to } 9.9 \mathrm{~g} \\
(n=32)\end{array}\end{array}$} & \multicolumn{2}{|c|}{$\begin{array}{l}\text { High Exposure } \\
\text { Accumulated Dose } \\
10 \text { to } 32 \mathrm{~g} \\
(\mathrm{n}=33)\end{array}$} & \multirow[t]{2}{*}{$P$ Value } \\
\hline & $\mathrm{N}$ & $\%$ & N & $\%$ & \\
\hline GO index & & & & & NS* \\
\hline 0 & 24 & 75.0 & 19 & 57.6 & \\
\hline$>0$ & 8 & 25.0 & 14 & 42.4 & \\
\hline MB index & & & & & NS* \\
\hline 0 & 19 & 59.4 & 13 & 39.4 & \\
\hline$>0$ & 13 & 40.6 & 20 & 60.2 & \\
\hline Gingival index (Gl) & & & & & NS* \\
\hline$\leq 1.5$ & 12 & 37.5 & 15 & 45.4 & \\
\hline$>1.5$ & 20 & 62.5 & 18 & 54.6 & \\
\hline Plaque index (PI) & & & & & NS* \\
\hline$\leq 2.5$ & 9 & 28.1 & 7 & 21.2 & \\
\hline$>2.5$ & 23 & 71.9 & 26 & 78.8 & \\
\hline
\end{tabular}

* Chi-square analysis collapsing categories: $\mathrm{GO}=0,>0 ; \mathrm{MB}=0,>0 ; \mathrm{GI}=\leq 1.5$, $>1.5 ; \mathrm{PI}=\leq 2.5,>2.5$.

Table 4.

Risk of Gingival Enlargement OR

\begin{tabular}{|c|c|c|c|c|c|c|}
\hline & \multicolumn{2}{|c|}{ Nifedipine } & \multicolumn{2}{|c|}{$\begin{array}{c}\text { Nifedipine } \\
\text { High Exposure }\end{array}$} & \multicolumn{2}{|c|}{$\begin{array}{c}\text { Nifedipine } \\
\text { Low Exposure }\end{array}$} \\
\hline & GO & $M B$ & GO & $M B$ & GO & $M B$ \\
\hline \multirow{6}{*}{ Gl - Adjusted } & 11.8 & 13.1 & 17.3 & 19 & 7.8 & 8.4 \\
\hline & $(4.5-30.6)$ & $(6-28.3)$ & $(5.9-50.8)$ & $(7.4-48.5)$ & $(2.4-24.8)$ & $(3.3-21.7)$ \\
\hline & 10.6 & 14.4 & 17.4 & 23.6 & 7.5 & 9.9 \\
\hline & $(3.8-29.1)$ & $(6-34.6)$ & $(5.3-56.3)$ & $(7.7-72.3)$ & $(2-27.1)$ & $(3.2-30.5)$ \\
\hline & 9.6 & 9.7 & 9 & 9.4 & 29.1 & 14.7 \\
\hline & $(3.3-28.1)$ & $(3.9-23.3)$ & $(2.5-32.7)$ & $(3-28.9)$ & $(3.5-240)$ & $(4.2-50.8)$ \\
\hline
\end{tabular}

$43 \% .{ }^{27,56}$ In our study, like others, lesions predominated and were more severe in the anterior and inferior teeth, especially vestibular. They also have been described at other sites including edentulous areas. ${ }^{19,20,64,65}$

With regard to the degree of gingival enlargement in association with cumulative doses of nifedipine, a greater prevalence of gingival overgrowth was found for both indices (GO and MB) in the high exposure group of patients, but the differences were not significant. Other studies have also failed to find a relationship between gingival enlargement and dose of the cal- cium antagonist and reported only that gingival overgrowth usually develops after 6 months of treatment. ${ }^{17,22,53,62,66,67}$ By contrast, some authors have stated that gingival overgrowth is dose dependent. ${ }^{68,69}$

The gingival index differed between groups and was associated with gingival enlargement. We did not find differences in the plaque index between groups. Other authors have found a relationship of gingival overgrowth with both the gingival and plaque indices. ${ }^{17,22,35,67}$ Because drug-induced gingival enlargement very often involves a combination of the effects of the drug and the inflammatory status, it is difficult to determine the contribution of each. In our study, the odds ratios (for all nifedipine-treated patients and for the subset of high nifedipine exposure) associated with inflammatory status (GI) were lower for both indices (GO and $M B$ ) than the OR associated with the effect of nifedipine. However, the ORs associated with the effect of nifedipine were higher in the subset of high nifedipine exposure than in the whole group of nifedipine-treated patients, while there were no differences with respect to the effect of the inflammatory status (GI) (Table 4). All together, this would suggest a possible dose/exposure-response associated with nifedipine treatment. To our knowledge, the risk of gingival enlargement attributable to nifedipine treatment has not been previously documented. ${ }^{70}$

Gingival overgrowth, which normally begins in the region of the interdental papilla, may favor the appearance of clinical symptoms and signs that include pain, bleeding and friability of the tissue, abnormal movement of the teeth, changes of appearance, phonetics, and occlusion, as well as the appearance of dental caries and other periodontal disorders. ${ }^{2,71}$ Surprisingly, for most of our patients with gingival enlargement, the condition was not noticed by either themselves or their clinicians, probably due to the fact that the gingival overgrowth was minimal (Table 2). Although usually there are no differences in the clinical characteristics of gingival overgrowth induced by different drugs, we previously reported a more severe degree of gingival enlargement in patients treated with phenytoin. ${ }^{72}$

The majority of indices used to quantify gingival overgrowth are unreliable because of their subjectivity or reproducibility difficulties. ${ }^{73,74}$ The present study used 2 indices that recorded vertical (GO) and horizontal $(M B)$ gingival enlargement. The MB index evaluates the nodullary papilla enlargement and results from a modification of the index. ${ }^{57,58,70,72}$ The Seymour index uses an indirect method based on a 3 dimensional study of plaster casts and evaluates only 
5 gingival units of the upper and lower anterior segments (from the midpoint of the right canine to the midpoint of the left canine). The index scores for each gingival unit are the result of the addition of gingival thickening (graded 0 to 2 ) and gingival encroachment (graded 0 to 3). ${ }^{57}$ The modification introduced in the present study (GO and MB index) offers the following advantages: 1 ) it permits the direct clinical recording of gingival enlargement (MB index) in the area of the interdental papilla, the region in which the dysmorphism first expresses itself, for the whole dentition, and 2 ) it records the 2 components of gingival enlargement at any site, differentiating between the degree of horizontal (MB index) and vertical (GO index) gingival enlargement. ${ }^{58}$ There were differences in the prevalence of gingival enlargement according to the index used (vertical versus horizontal registers). This has also been described in other studies. ${ }^{17,29}$ One possible explanation is that the MB index detects gingival overgrowth at earlier stages of enlargement than the GO index. The concordance between both measurements, however, confirmed their reliability.

In our study, we found a significant difference between both groups in relation to age and tobacco smoking, which could be explained by the nature of cardiovascular diseases that affects older individuals and by the fact that most of the patients had quit smoking. Other authors consider that neither age nor gender appears to be a determinate factor of drug-induced gingival enlargement. ${ }^{19-21,53}$ A relationship between oral breathing patterns and gingival overgrowth was not observed in the present study, but it has been reported in patients treated with phenytoin. 7,75

It has been shown that nifedipine-induced gingival enlargement may be reduced or prevented by good plaque control, aimed at reducing gingival inflammation, and that in the most severe cases, resective periodontal surgery is used to eliminate excess tissue. ${ }^{76-80}$ Also, wherever possible, reducing the drug dose or replacing it with another agent should be considered. ${ }^{25,81}$ In our case, alternatives to nifedipine include the other dihydropyridines or non-dihydropyridine calcium antagonists, although verapamil ${ }^{24,25}$ and diltiazem ${ }^{29,30}$ also have been related to gingival enlargement. As an example, Westbrook et al. ${ }^{82}$ reported that replacing nifedipine by isradipine reduced the severity of gingival enlargement in $60 \%$ of patients. Metronidazole and azithromycin have been recently used to treat gingival enlargement induced by cyclosporin $A$, resulting in a reduction or even resolution of the overgrowth. ${ }^{83-86}$ It is unknown whether this effect is related to the antimicrobial action of these drugs or to other mechanisms. ${ }^{83}$

Clinicians should be aware of the prevalence and risk of gingival overgrowth induced by nifedipine in order to implement preventive measures and estab- lish an early diagnosis. Regular visits to a periodontist when this drug is used is highly advisable.

\section{ACKNOWLEDGMENTS}

This work was supported by a doctorate fellowship from the Health Sciences Division of the University of Barcelona. The authors thank Dr. Marta Pulido for editorial assistance and Dentaid, S.L., Barcelona, Spain for the supply of oral hygiene products used in the study.

\section{REFERENCES}

1. Brunet Ll, Miranda J, Farré M, Berini L, Mendieta C. Gingival enlargement induced by drugs. Drug Safety 1996; 15:219-231.

2. Carranza FA. Gingival enlargement. In: Carranza FA, ed. Glickman's Clinical Periodontology. Philadelphia: W.B. Sanders Co.; 1990:125-148.

3. Hassell TM. Local and systemic actions of drugs and other chemical agents on periodontal tissues. In: Genco RJ, Goldman HM, Cohen DW, eds. Contemporary Periodontics. St. Louis: The CV Mosby Co.; 1990:269-276.

4. Mendieta C. Classification of periodontal diseases. Avances Odontoestomatología 1995;11(Suppl. B):135143.

5. Angelopoulos AP, Goaz PW. Incidence of diphenylhydantoin hyperplasia. Oral Surg Oral Med Oral Pathol 1972;34:898-906.

6. Kimball OP. The treatment of epilepsy with sodium diphenylhydantoinate. JAMA 1939;112:1244-1245.

7. Peñarrocha M, Bagan JV, Antolina MM, Alfaro A. Gingival enlargement induced by phenytoin. Revista Europea Odontoestomatología 1989;1:41-48.

8. Adams D, Davies G. Gingival hyperplasia induced by cyclosporin A. A report of two cases. Br Dent J 1984; 157:89-90.

9. Bennett JA, Christian JM. Cyclosporine-induced gingival hyperplasia: Case report and literature review. $J$ Am Dent Assoc 1985;111:272-273.

10. Britton S, Palacios R. Cyclosporin A - Usefulness, risks and mechanism of action. Immunol Rev 1982;65:5-21.

11. Hassell TM, Hefti AF. Drug-induced gingival overgrowth: Old problem, new problem. Crit Rev Oral Biol Med 1991; 2:103-137.

12. Hefti AF, Eshenaur AE, Hassell TM, Stone C. Gingival overgrowth in cyclosporine A treated multiple sclerosis patients. J Periodontol 1994;65:744-749.

13. Rateitschak-Plüss E, Hefti A, Loertscher R, Thiel G. Initial observation that cyclosporin-A induces gingival enlargement in man. J Clin Periodontol 1983;10:237246.

14. Morisaki I, Akiyama YM, Miyawaki YN, Mori Y. Positive correlation between blood cyclosporin A level and severity of gingival overgrowth in rats. J Periodontol 1997;68: 7-11.

15. Somacarrera ML, Hernández G, Acero J, Moskow BS. Factors related to the incidence and severity of cyclosporin-induced gingival overgrowth in transplant patients. A longitudinal study. J Periodontol 1994;65:671675.

16. Wondimu B, Sandberg J, Modéer T. Gingival overgrowth in renal transplant patients administered cyclosporin A in mixture or in capsule form. A longitudinal study. Clin Transplant 1996;10:71-76.

17. Bullón P, Machuca G, Martinez-Sahuquillo A, Rios JV, Rojas J, Lacalle JR. Clinical assessment of gingival 
hyperplasia in patients treated with nifedipine. J Clin Periodontol 1994;21:256-259.

18. Carranza FA Jr. Endocrinologic influences on the periodontium. In: Carranza FA Jr., ed. Glickman's Clinical Periodontology. Philadelphia: W.B. Saunders Co.; 1990: 444-459.

19. Lederman D, Lummermann M, Reuben S, Freedman PD. Gingival hyperplasia associated with nifedipine therapy. Oral Surg Oral Med Oral Pathol 1984;57:620-622.

20. Lucas RM, Howell L, Wall B. Nifedipine-induced gingival hyperplasia: A histochemical and ultrastructural study. J Periodontol 1985;56:211-215.

21. Ramon Y, Behar S, Kishon Y, Engelberg I. Gingival hyperplasia caused by nifedipine. A preliminary report. Int J Cardiol 1984;5:195-204.

22. Seymour RA. Calcium channel blockers and gingival overgrowth. Br Dent J 1991;170:376-379.

23. Cucchi G, Giustianini S, Robustelli F. Gingival hyperplasia caused by verapamil. Ital J Cardiol 1985;15:556557.

24. Miller CS, Damm DD. Incidence of verapamil-induced gingival hyperplasia in a dental population. J Periodontol 1992;63:453-456.

25. Pernu HE, Oikarinen K, Hietanen J, Knuuttila M. Verapamil-induced gingival overgrowth: A clinical, histologic and biochemic approach. J Oral Pathol Med 1989; $18: 422-425$.

26. Smith M, Glenert U. Gingival hyperplasia caused by verapamil treatment (in German). Tandlaegebladet 1987;91: 849.

27. Steele RM, Schuna AA, Schreiber RT. Calcium antagonist-induced gingival hyperplasia. Ann Intern Med 1994; 120:663-664.

28. Bowman J, Levy B, Grubb R. Gingival overgrowth induced by diltiazem. Oral Surg Oral Med Oral Pathol 1988;65:183-185.

29. Bullón P, Machuca G, Martínez Sahuquillo A, et al. Clinical assessment of gingival size among patients treated with diltiazem. Oral Surg Oral Med Oral Pathol Oral Radiol Endod 1995;79:300-304.

30. Colvard MD, Bishop J, Weissman D, Bargiulo AV. Cardizem-induced gingival hyperplasia. Periodont Case Rep 1986;8:67-68.

31. Fattore L, Stablein M, Bredfeldt G, Semla T, Moran M, Doherty-Greenberg JM. Gingival hyperplasia: A side effect of nifedipine and diltiazem. Spec Care Dent 1991;11:107-109.

32. Giustiniani S, Della Cuna FR, Marien M. Hyperplastic gingivitis during diltiazem therapy. Int J Cardiol 1987; 15:247-249.

33. Akimoto Y, Tanaka S, Omata H, et al. Gingival hyperplasia induced by nifedipine. J Nihon Univ Sch Dent 1991;33:174-181.

34. Sooriyamoorthy $M$, Gower DB. Drug induced gingival overgrowth: Clinical features and possible mechanisms. Med Sci Res 1989;17:881-884.

35. Atilla G, Kütükçuler N. Crevicular fluid interleukin-1 $\beta$, tumor necrosis factor- $\alpha$, and interleukin- 6 levels in renal transplant patients receiving cyclosporine A. J Periodontol 1998;69:784-790.

36. Fujii A, Kobayashi S. Nifedipine inhibits calcium uptake of nifedipine-sensitive gingival fibroblast. J Dent Res 1990;69(Spec. Issue):332(Abstr. 1789).

37. Fujii A, Matsumoto H, Nakao S, Teshigawara H, Akimoto Y. Effect of calcium-channel blockers on cell proliferation, DNA synthesis and collagen synthesis of cultured gingival fibroblasts derived from human nifedipine responders and non-responders. Arch Oral Biol 1994; 39:99-104.

38. Offenbacher S. Effects of dilantin on monocytic growth factors. J Periodontol 1993;64:237-238.

39. Van der Wall E, Tuinzing D, Hes J. Gingival hyperplasia: A possible side effect of nifedipine. Ned Tijdschr Geneeskd 1984;128:1954-1955.

40. Henderson JS, Flynn JC, Tucci MA, et al. Site-specific variations in metabolism by human fibroblasts exposed to nifedipine in vitro. J Oral Pathol Med 1997;26:6-10.

41. Newell J, Irwin CR. Comparative effects of cyclosporin on glycosaminoglycan synthesis by gingival fibroblasts. $J$ Periodontol 1997;68:443-447.

42. Hassell T. Evidence that cyclosporine, phenytoin and dihydropiridines elicit overgrowth by different mechanisms. J Dent Res 1990;69(Spec. Issue)164(Abstr. 447).

43. Peñarrocha-Diago M, Bagan-Sebastian JV, Vera-Sempere F. Diphenylhydantoin-induced gingival overgrowth in man: A clinico-pathological study. $J$ Periodontol 1990;61:571-574.

44. Flórez J. Antihypertensive drugs. In: Flórez J, ed. Farmacología Humana. Barcelona: Ed. Científicas y Técnicas; 1992:587-589.

45. Tamargo J, Delpón E. Pharmacology of heart failure II. Ionotropic and vasodilator drugs. In: Flórez J, ed. Farmacología Humana. Barcelona: Ed. Científicas y Técnicas; 1992:549-554.

46. Brown RS, Beaver WT, Bottomley WK. On the mechanism of drug-induced gingival hyperplasia. J Oral Pathol Med 1991;20:201-209.

47. Nagano S, Ogawa T, Fukuyama S, et al. Influence of nicardipine hydrochlorhide on hypotensive effect and insulin secretion in a patient of hypertensive diabetic mellitus. Jpn Pharmacol Ther 1985;19:5309-5313.

48. Pascual-Castroviejo I, Pascual I. Gingival hyperplasia induced by nicardipine. Neurología 1997;12:37-39.

49. Lombardi T, Fiore-Donno G, Belser U, Di Felice R. Felodipine-induced gingival hyperplasia: A clinical and histologic study. J Oral Pathol Med 1991;20:89-92.

50. Juncadella García E, Fandos Olona JM, Alba Granados J, Descarrega Queralt R. Gingival hyperplasia induced by amlodipine. Med Clin (Spain) 1994;103:358-359.

51. Seymour RA, Ellis JS, Thomason JM, Shibutani J, Nakano Y, Kaneko K. Amlodipine-induced gingival overgrowth. J Clin Periodontol 1994;21:281-283.

52. Jorgensen MG. Prevalence of amlodipine-related gingival hyperplasia. J Periodontol 1997;68:676-678.

53. Bencini PL, Crosti C, Sala F, Ambroso GC, Marini D. Gingival hyperplasia induced by nifedipine. Giorn It Derm Vener 1986;121:29-31.

54. Doria G, Cangemi F, Gulizia M, Lo Giudice P, Circo A. Three cases of gingival hyperplasia during treatment with nifedipine. Minerva Cardioangiol 1990;38:97-100.

55. Tavassoli S, Yamalik N, Çaglâyan F, Çaglâyan G, Eratalay K. The clinical effects of nifedipine on periodontal status. J Periodontol 1998;69:108-112.

56. Moreu G, González-Jaranay M, Gijón JJ, Otero A. Gingival enlargement induced by nifedipine in a population of patients with cardiovascular disease. Clinical study (in Spanish). Arch Odonto Estomatol 1995; 11:249-255.

57. Seymour RA, Smith DG, Turnbull DN. The effects of phenytoin and sodium valproate on the periodontal health of adult epileptic patients. J Clin Periodontol 1985; 12:413-419.

58. Miranda J, Brunet Ll, Roset PN, Farré M, Berini L, Mendieta $C$. Prevalence and risk for gingival enlargement 
induced by calcium channel blockers (abstract). Int Dent $J$ 1998;48:450.

59. Löe H, Silness J. Periodontal disease in pregnancy. I. Prevalence and severity. Acta Odontol Scand 1963;21: 533-551.

60. Quigley GA, Hein JW. Comparative classifying efficiency of normal and power brushing. J Am Dent Assoc 1962; 65:26-29.

61. Listgarten MA. Periodontal probing: What does it mean? $J$ Clin Periodontol 1980;7:165-176.

62. Barclay S, Thomason JM, Idle JR, Seymour RA. The incidence and severity of nifedipine-induced gingival overgrowth. J Clin Periodontol 1992;19:311-314.

63. Pocock SJ. The size of a clinical trial. In: Pocock SJ, ed. Clinical Trials. A Practical Approach. London: John Wiley E Sons; 1984:123-141.

64. Bencini PL, Crosti C, Sala F, et al. Gingival hyperplasia by nifedipine. Report of a case. Acta Derm Venereol 1985;65:362-365.

65. Sauget P, Monteil RA, Monrad P, Loubiere R, Lapalus P, Haudebourg $C$. Gingival hyperplasia secondary to the use of calcium antagonists: Analysis. J Biol Buccale 1992;20:25-32.

66. Meirnyska A, Abrahamnyska M, Gotsman M. Nifedipineinduced gingival hyperplasia: Case reports and literature review. Isr J Med Sci 1989;25:453-455.

67. Nery E, Edson R, Lee K, Pruthi V, Watson J. Prevalence of nifedipine-induced gingival hyperplasia. J Periodontol 1995;66:572-578.

68. Barak S, Engelberg IS, Hiss J. Gingival hyperplasia caused by nifedipine. Histopathological findings. J Periodontol 1987;58:639-642.

69. Cleary JD. Nifedipine-induced gingival overgrowth. Ann Pharmacother 1997;31:922-923.

70. Miranda J. Gingival dismorphism. A study of prevalence of gingival enlargement in patients treated with calcium channel blockers. [Thesis]. Barcelona, Spain: Universitat de Barcelona; 1997:256-271.

71. Fu E, Nieh S, Wikesjö UME, Fu-Gong L, Shen EC. Gingival overgrowth and dental alveolar alterations: Possible mechanisms of cyclosporin-induced tooth migration. An experimental study in the rat. J Periodontol 1997;68: $1231-1236$.

72. Brunet Ll. Gingival dismorphism. A study of prevalence of gingival enlargement in patients treated with antiepileptics. [Thesis]. Barcelona, Spain: Universitat de Barcelona; 1998;307 p.

73. Grant RH, Parsonage MJ, Barot MH. Phenytoin-induced gum hypertrophy in patients with epilepsy. Curr Med Res Opin 1988;10:652-655.

74. Slavin J, Taylor J. Cyclosporin, nifedipine, and gingival hyperplasia (letter to the editor). Lancet 1987;2:739.

75. Hassell TM, O'Donnell J, Pearlman J, Tesini D, Murphy $\mathrm{T}$, Best H. Phenytoin-induced gingival overgrowth in institutionalized epileptics. J Clin Periodontol 1984;11:242253.

76. Kieser JB. Simple pockets surgery: II. Soft tissue resection technique. In: Kieser JB, ed. Periodontics. A Practical Approach. London: Wright; 1990:187-225.

77. Hancock RH, Swan RH. Nifedipine-induced gingival overgrowth. J Clin Periodontol 1992;19:12-14.

78. Modéer T, Dahllöf G, Theorell K. Oral health in noninstitutionalized epileptic children with special reference to phenytoin medication. Community Dent Oral Epidemiol 1986;14:165-168.
79. Seymour RA, Smith DG. The effect of a plaque control programme on the incidence and severity of cyclosporininduced gingival changes. J Clin Periodontol 1991;18: 107-110.

80. Pilloni A, Camargo PM, Carere M, Carranza FA. Surgical treatment of cyclosporine A- and nifedipine-induced gingival enlargement: Gingivectomy versus periodontal flap. J Periodontol 1998;69:791-797.

81. Nishikawa S, Tada H, Hamasaki A, et al. Nifedipineinduced gingival hyperplasia: A clinical and in vitro study. $J$ Periodontol 1991;62:30-35.

82. Westbrook P, Bednarczyk EM, Carlson M, Sheehan H, Bissada NF. Regression of nifedipine-induced gingival hyperplasia following switch to a same class calcium channel blocker, isradipine. J Periodontol 1997;68:645650.

83. Cecchin E, Zanello F, De Marchi S. Treatment of cyclosporine-induced gingival hypertrophy. Ann Intern Med 1997;126:409-410.

84. Wahlström E, Zamora JU, Teichman S. Improvement in cyclosporin-associated gingival hyperplasia with azithromycin therapy. New Engl J Med 1995;332:753754.

85. Wong W, Hodge MG, Lewis A, Sharpstone P, Kingswood JC. Resolution of cyclosporin-induced gingival hypertrophy with metronidazole (letter to the editor). Lancet 1994;343:986.

86. Nash MM, Zaltzman JS. Efficacy of azithromycin in the treatment of cyclosporine-induced gingival hyperplasia in renal transplant recipients. Transplantation 1998;65: 1611-1615.

Send reprint requests to: Dr. Carlos Mendieta, Periodontics Unit, Facultat d'Odontologia, Universitat de Barcelona, Feixa Llarga, s/n. E-08907-L'Hospitalet de Llobregat, Barcelona, Spain. Fax: 34-93-3304767; e-mail: mendieta@ bellvitge.bvg.ub.es

Accepted for publication November 20, 2000. 